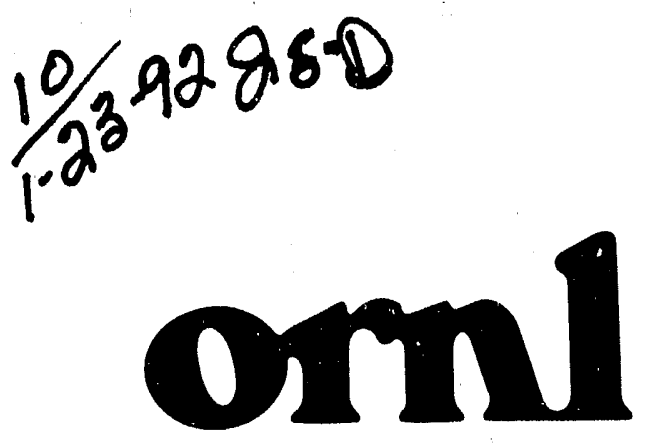

OAK RIDGE NATIONAL LABORATORY

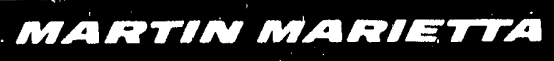

\title{
MAINTAINING ELECTRIC POWER SYSTEM PERFORMANCE: PREPARING FOR THE YEAR 2020
}

\author{
RESEARCH NEEDS
}

S. J. Dale

J. P. Stovall

K. W. Klein

Published November 1991

Prepared for the

U. S. Department of Energy

Assistant Secretary, Conservation and Renewable Energy Washington, DC 20585

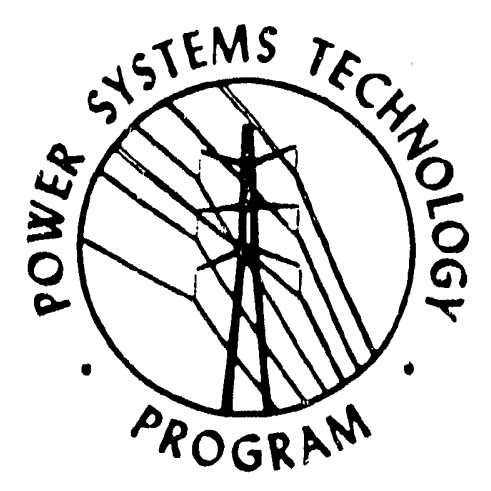

\section{MANAGED BY}

Prepared by

OAK RIDGE NATIONAL LABORATORY managed by

MARTIN MARIETTA ENERGY SYSTEMS, INC.

for the

U.S. DEPARTMENT OF ENERGY

under Contract No. DE-AC05-84OR21400

MARTIN MARIETTA ENERGY SYSTEMS, INC.

FOR THE UNITED STATES

DEPARTMENT OF ENERGY 
This report has been reproduced directly from the best available copy.

Available to DOE and DOE contractors from the Office of Sclentfic and Technical Information, P.O. Box 62, Oak Ridge, TN 37831; prices available from (615) 576-8401, FTS 626-8401.

Avallable to the public from the National Technical Information Service, U.S. Department of Commercu, 5285 Port Royel Rd., Springfield, VA 22161.

This report was prepared as an account of work sponsored by an agency of the United States Government. Neither the United States Government nor any agency thereof, nor any of their employees, makes any warranty, express or implied, or assumes any legal liability or responsibility for the accuracy, completeness, or usefulness of any information, apparatus, product, or process disclosed, or represents that its use would not infringe privately owned rights. Reference herein to any specific commercial product, process, or service by trade name, trademark, manuiacturer, or otherwise, does not nscessarily constitute or imply its endorsement, recommendation, or favoring by the United States Government or any agency thereof. The views and opinions of authors expressed herein do not necessarily state or reflect those of the United States Government or any agency thereof. 


\section{MAINTAINING ELECTRIC POWER SYSTEM PERFORMANCE:}

Preparing for the Year 2020

Research Needs

S. J. Dale

DE92 005517

J. P. Stovall

Energy Division

K. W. Klein

Consultant

Manuscript completed April 1991

Published November 1991

\section{Prepared for the}

U. S. Department of Energy

Assistant Secretary, Conservation and Renewable Energy Washington, DC 20585

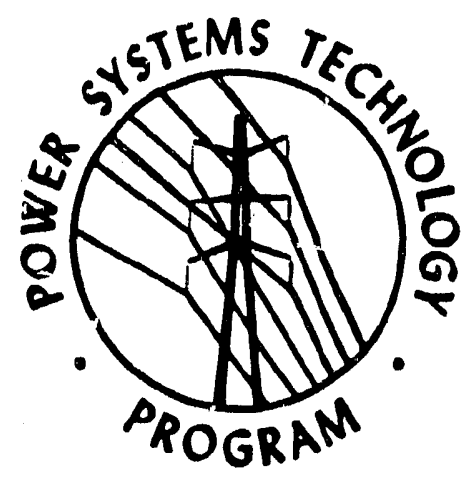

Prepared by

OAK RIDGE NATIONAL LABORATORY

managed by

MARTIN MARIETTA ENERGY SYSTEMS, INC.

for the

U.S. DEPARTMENT OF ENERGY

under Contract No. DE-AC05-84OR21400

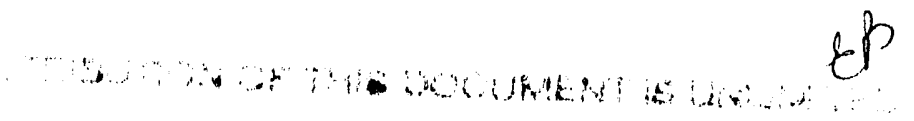




\section{CONTENTS}

LIST OF TABLES $\ldots \ldots \ldots \ldots \ldots \ldots \ldots \ldots \ldots \ldots \ldots \ldots \ldots$

EXECUTIVE SUMMARY $\ldots \ldots \ldots \ldots \ldots \ldots \ldots \ldots \ldots \ldots \ldots \ldots$ vii

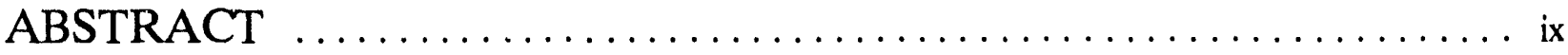

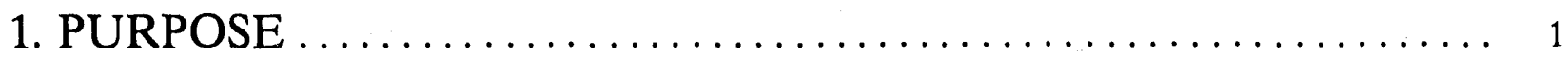

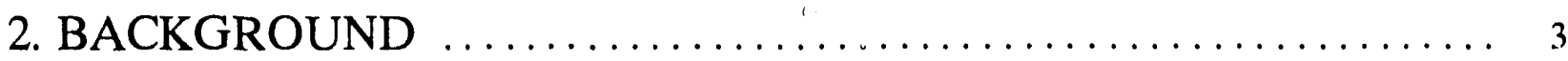

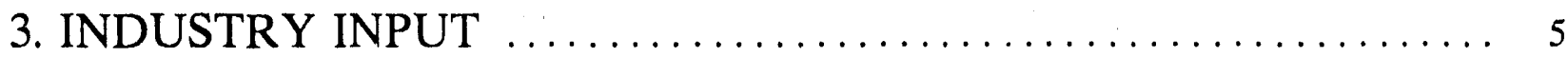

4. SYSTEM 2020 AND ITS CHANGING DYNAMIC

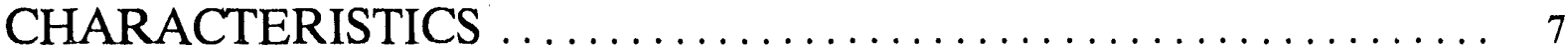

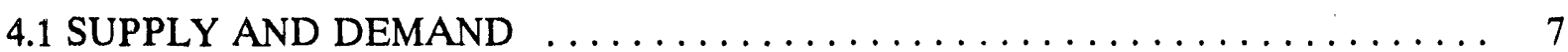

4.2 TRANSMISSION AND DISTRIBUTION $\ldots \ldots \ldots \ldots \ldots \ldots \ldots \ldots \ldots, 8$

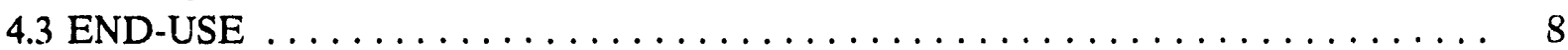

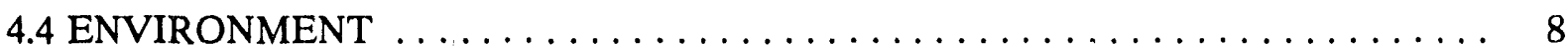

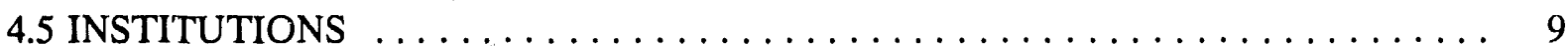

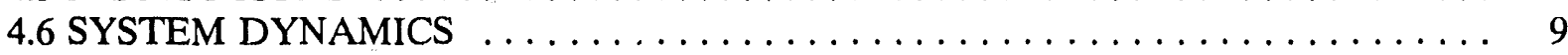

5. REQUIRED RESEARCH $\ldots \ldots \ldots \ldots \ldots \ldots \ldots \ldots \ldots \ldots \ldots \ldots \ldots . \ldots \ldots$

5.1 EFFECTS OF EXPOSURE TO ELECTRIC AND MAGNETIC FIELDS $\ldots \ldots \ldots 11$

5.2 REAL-TIME POWER SYSTEM CONTROL $\ldots \ldots \ldots \ldots \ldots \ldots \ldots \ldots \ldots, 13$

5.3 HIGHER-CAPACITY TRANSMISSION OPTIONS $\ldots \ldots \ldots \ldots \ldots \ldots \ldots \ldots . \ldots \ldots$

5.4 HIGH-CAPACITY POWER ELECTRONICS $\ldots \ldots \ldots \ldots \ldots \ldots \ldots \ldots \ldots$

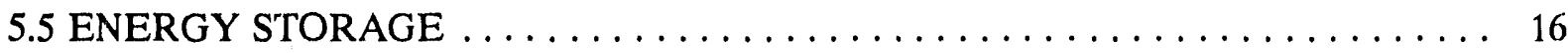

6. RESEARCH LEADERSHIP ........................ 17

ACKNOWLEDGMENTS ................................. 19

APPENDIX A: STRAWMAN SYSTEM $2020 \ldots \ldots \ldots \ldots \ldots \ldots \ldots$ A-1

APPENDIX B: AGENDA $\ldots \ldots \ldots \ldots \ldots \ldots \ldots \ldots \ldots \ldots \ldots \ldots \ldots \ldots \ldots$

APPENDIX C: LIST OF PARTICIPANTS $\ldots \ldots \ldots \ldots \ldots \ldots \ldots \ldots$ C-1 


\section{LIST OF TABLES}

Table 1. Seven states with field-strength limits for transmission line rights-of-way $\ldots \ldots \ldots 12$

Table 2. Support for research and development in electrical systems in 1989, selected groups $\ldots \ldots \ldots \ldots \ldots \ldots \ldots \ldots \ldots \ldots \ldots \ldots \ldots \ldots \ldots$ 


\section{EXECUTIVE SUMMARY}

This report details the results of a meeting of the Department of Energy (DOE), DOE contractors, the DOE Power Marketing Agencies [Bonzeville Power Administration (BPA) and Western Area Power Administration (WAPA)], and a number of rescarch and development managers from the electric utility industry and associations. The partipants developed perspectives on the electric power delivery system of the future and outlined thi $t$ search and development (R\&D) issues that need attention to successfully maintain the performance of the power delivery system through the year 2020.

Many factors will influence the dynamic characteristics of the electric power system by the year 2020. Of particular importance will be the increase in smaller, dispersed generators that are outside of direct utility control and that will need access to the transmission system, and the utilization of dispersed storage facilities for peaking power and system stability and control. The increasing use of transmission lines for bulk power transfers and the growing demand for access by non-utility generators will continue to stress the transmission system. In addition, because of the difficulty in obtaining new rights-of-way, the use of transmission corridors, new or existing, must be maximized by increasing the amount of power that can be transmitted through these corridors. All these corditions will require closer control of power dispatch and power flow, which in turn will require (1) technologies and procedures for handling massive amounts of data, (2) real-time control capability, and (3) faster and larger system modeling capabilities than are presently available. The major areas that were identified for increased research and development to meet the challenges of system needs by the year 2020 include the following:

- Effects of Exposure to Electric and Magnetic Ficlds (EMFs). The issuc of health effects from exposure to EMFs requires urgent consideration on both short-term and long-term bases and must be dealt with within the next five to ten years. The top priority should be to determine if a safe level of exposure to magnetic fields exists. The specific actions needed include providing national leadership (which includes improving public education, identifying technical issues, and developing national standards), continuing scientific studies on biological systems, and developing mitigation method options.

- Real-Time Power System Controls. Real-time power system controls and faster data analysis capabilities will be an absolute requirement to maintain system stability and the high reliability of the electric supply. Important targets for research are system architecture, new modeling techniques, control schemes, computers, communication and sensor technology, and information management methods.

- Higher-Capacity Transmission Options. The transmission system capability must be increased to meet the new demands and to overcome the restrictions placed on upgrading and new sitings. Joint planning should be considered for use of rights-of-way by the various utilities and states. Areas that are important $R \& D$ issues include greater transmission capacity, advanced transmission concepts, new materials, more efficient components, and improved maintenance.

- High-Capacity Power Electronics. Power electronics will play a kcy role in controlling load flow, increasing transmission capacity, and facilitating integration of renewable and intermittent generation into the system, because this technology can provide the much greater speed and flexibility needed. Power electronic devices with higher current and voltage ratings than are presently available must therefore be developed. Identified areas for R\&D are converter 
equipment for high-voltage ac/dc, interrupting equipment (circuit breakers), and near-rcal-time control of load flow.

- Energy Storage. Energy storage has the potential to alleviate the need to match generation capacity with demand at all times, as well as to defer construction of new generation and transmission facilities. The total system benefit of energy storage must be determined, including the costs; the optimal sizes and locations of storage sites in the electric utility system; and the contribution to system stability, load flow, and control. The development of storage technology for electric utility applications should continue. 


\begin{abstract}
The U.S. electric power delivery system will undergo dramatic changes between now and the year 2020. Without an aggressive research and development (R\&D) program to develon and integrate new technologies, a substantial mismatch could develop between the system's performance and the public's expectations for a stable, reliable source of energy. This report provides a perspective on the future U.S. electrical power delivery system and outlines the major issucs for R\&D support that will be required to rnaintain the performance of the system successfully through the year 2020 .

To define the R\&D needs in the electric utility sector, the U.S. Department of Energy (DOE) Office of Energy Management under the Assistant Secretary for Conservation and Renewable Energy, in participation with the Bonneville Power Administration (BPA) and the Western Area Power Administration (WAPA), met with electric utility industry leaders in Denver, Colorado, on March 19 and 20, 1990.

The major areas that require increased $R \& D$ in order to meet the challenges of system needs by the year 2020 include the following:

- Effects of exposure to electric and magnetic ficlds (EMFs). The issue of health effects from exposure to EMFs requires urgent consideration, both on short-term and long-term bases, and must be addressed within the next five to ten years. The top priority should be to determine if there is a safe level of exposure to magnetic fields.

- Real-time power system control. Faster real-time power system controls and faster data analysis capabilities will become absolute requirements to maintain the system stability and the high reliability of the electric supply. Important targets for research are system architecture, new modeling techniques, computers, communication and sensor technology, and information management methods.

- Higher-capacity transmission options. The transmission system capability must be increased to meet the new demands and to overcome the restrictions placed on upgrading and new sitings. Joint planning should be considered for use of rights-of-way by the various utilitics and states. Areas that are important R\&D issues include adequate transmission capacity, advanced transmission concepts, new materials, components, and improved maintenance.

- High-capacity power electronics. Power electronics will play a key role in controlling load flow; increasing transmission capacity; and facilitating integration of renewable, intermittent gencration into the system, because this technology can provide the much greater speed and flexibility needed. Therefore, power electronic devices with higher current and voltage ratings than are currently available must be developed. Identified areas for R\&D are converter equipment for high voltage ac/dc, interrupting equipment, and control of load flow.

- Energy storage. Energy storage potentially can alleviate the need to match generation capacity with demand at all times. The total system benefit of energy storage must be determined, including the costs and the optimal sizes and locations of storage sites in the electric utility system. The development of stiorage technology for electric utility applications should continue.

An electric energy delivery system that reliably supplies sufficient electric power at the lowest possible cost to meet the nation's needs is vital to the economic health of the U.S. In order to meet the challenges facing the national supply and delivery of electric power in the future, all parties concerned with the R\&D of supply and delivery technologies for electric energy must coopecate and must seek to leverage the limited funds available.
\end{abstract}




\section{PURPOSE}

This report provides an industry perspective on the future U.S. electrical power delivery system and outlines the major issues for research and development (R\&D) support that will be required to * successfully meet demands while maintaining system performance through the year 2020 . The year 2020 was chosen as a target because technological changes from $R \& D$ that are already in progress or that will be initiated over the next several years will be substantially in place in the utility industry by that year. This perspective and this outline of $R \& D$ needs are a result of a mecting with representatives from a cross section of the electric utility industry. 


\section{BACKGROUND}

The U S. electric power delivery system will undergo dramatic changes between now and the year 2020. Without an aggressive R\&D program to develop and integrate new technologies, a substantial mismatch could develop between the system's performance and the public's expectations for a stable, reliable source of energy.

Several factors affect the evolutionary path of the electric power delivery system to the year 2020 . These include

- environmental concerns such as air quality, greenhouse effecis, electric and magnetic ficlds (EMFs), and radioactive and toxic waste disposal;

- the regulatory process, with independent ownership of poiver plants, wheeling of power, and transmission access;

- the competitiveness of the industry;

- new and changing generation, transmission, and distribution technologies;

- new and changing demand-side technologies;

- load growth;

- construction of new facilities and life extension of older facilities; and

- the emergence of renewable energy sources and electric encrgy storage techniques and their integration into the system.

Both private and government-owned electric utilities are faced with these issues, and many other issues are certain to emerge. All of these factors will change the dynamics of the electric power system in the future, will make operation and controls different from what they are today, and can have substantial impact on the reliability and security of the system. To avoid the losses in reliability and security that could result in substantial economic loss if these issues are not addressed in a timely manner, a broad-based basic and applied $R \& D$ program must be implemented in the area of electric power delivery systems. 


\section{INDUSTRY INPUT}

To define the R\&D needs in the electric utility sector, the U.S. Department of Energy (DOE) Office of Energy Management (formerly Office of Energy Storage and Distribution) under the Assistant Secretary for Conservation and Renewable Energy, in participation with the Bonneville Power Administration (BPA) and the Western Area Power Administration (WAPA), met with electric utility industry leaders in Denver, Colorado, on March 19 and 20, 1990. The participants at the meeting were executives representing five private utilities, five public utilitics, and nine organizations from various segments of the electric utility industry [e.g., American Public Power Association, Edison Electric Institute, Electric Power Research Institute (EPRI), National Institute of Standards and Technology, and National Rural Electric Cooperative Association). Sce Appendix $B$ for the agenda and Appendix $C$ for the list of participants.

"System 2020," a vision of the power system in the year 2020, was developed earlier by DOE, BPA, and WAPA as a "strawman" scenario (shown in Appendix A). This scenario was used as the starting point for the discussions at the March meeting and generally was accepted by the attendees. The final section of Appendix A summarizes the conclusions about the challenges that must be met for System 2020. 


\section{SYSTEM 2020 AND ITS CHANGING DYNAMIC CHARACTERISTICS}

The development of System 2020 and its required research were driven by the concern that the dynamic characteristics of the electric power system by 2020 cannot be adequately controlled without substantial change from today's state-of-the-art technology.

Two key questions were considered by the group:

1. How will the dynamic characteristics of the electric power system change by the year 2020 ?

2. What R\&D will be tequired to ensure a stable and reliable power system under these conditions?

Several factors were considered to influence the dynamic behavior of the power system. These include factors of supply, such as generator type and size, unit location, and variability of resources (e.g., wind and solar); the influence of the growing demand and changing end-use technologies; the increasing need for the transmission system to accommodate the growth in demand and disparity of generation resources; the impact of environmental constraints; the aging of the power system; and the changing regulatory climate. The discussion on these topics and their influence on the dynamics of the power system is summarized in the remainder of this section. Section 5 outlines the five most important R\&D categories identified by the industry participants.

\subsection{SUPPLY AND DEMAND}

It was assumed that load growth will continue at approximately $3 \%$ per year, increasing the need for additional power by $745 \mathrm{GW}$ over the 1989 summer peak demand of $522 \mathrm{GW} .^{1}$ It was also assumed that the increase in the number of central generating stations will not be sufficient to meet the load growth, but that the growth in non-utility generators (NUGs) will continue. The North American Electric Reliability Council (NERC) estimates that by 1998 almost 30 GW of NUGs will be in use, representing 3.6\% of the total planned capacity resources. ${ }^{1}$ It was assumed that by 2020 over $50 \%$ of all new generating units will be non-utility owned. Power-plant unit size is also expected to be smaller than that of plants presently in use, ranging in unit size from $50 \mathrm{MW}$ to $600 \mathrm{MW}$.

The nuclear option will not be considered in System 2020 until the issues of spent fucl storage and waste handling have been resolved, but by 2020 nuclear plants will be standardized and smaller in size than present plants. Twenty percent of the electricity supply will be generated from renewable sources, and energy storage will provide $10 \%$ of system peak load. The generators will be both utility owned and non-utility owned, and many will operaie in a co-generating mode. Coordination of these varied generation sources for economic dispatch will become more difficult and will require new, sophisticated control equipment and strategies. Superconducting generators will become available late in this period, and their particular dynamic characteristics must also be accommodated by the dispatch, control, and protection system.

${ }_{1}^{1} 1989$ Reliability Assessment, The Future of Bulk Electric System Reliability in North America 1989.1998, North American Electric Reliability Council, September 1989. 


\subsection{TRANSMISSIUN AND DISTRIBUTION}

The stress on the transmission system will continue to increase as demand for bulk power transfers increases and as the NUGs gain unlimited access. Because of difficultics in obtaining rightsof-way for new lines and permission to upgrade sxisting lines, the ability to transmit bulk power will be limited as the loading on existing lines reaches full capacity. Lack of resolution for this situation will reduce reliability and increase outages, as well as act as a bariter to investment in non-utility generation.

New generating plants-particularly NUGs, renewable energy source generators, and storage plants-will be more dispersed throughout the system. This dispersion could decrease the stress on transmission. However, it will also increase the need for system automation, better controllability such as near-real-time controls, and fast predictive models for planning and dispatch as a result of the need for increased interconnections.

Increasing market penetration of superconducting technology, ranging from generators to transmission lines to storage devices, will change the system dynamics, requiring more and faster controls.

More interregional ties will become necessary to maintain reliability and system stability and to facilitate the coordination of power delivery from regions with supply to those with demand.

The prospects for increasing the transmission loading while maintaining reliability will depend upon the particular electric utility's ability to precisely monitor and control the power network. Managing the transmission system and power flow will require utilitics to use real-time data and nearor real-time controls to increase loading and power transfers, as well as to take advantage of the timeand site-specific dynamic rating of the lines. More powerful models will be required to account for larget control areas, increased interconnections, and large volumes of data. These models will necd to use sophisticated algorithms and supercomputers.

As the system becomes loaded closer to its thermal and stability limits and is increasingly interconnected, it will be more vulnerable to power system disturbances. The disturbances can originate from natural sources such as geornagnetic storms and lightning, from system sources such as power system operations, and from electromagnetic pulses.

EMF concerns will be a major force in limiting the options for power transmission over the next ten years.

\subsection{END-USE}

A number of changes will take place that will make socicty more vulncrable to disruptions in electricity supply. These include "just-in-time" manufacturing and electronic transfer of funds and information. Demand-side management will increase and will result in greater interaction with the customer load, as well as change dynamic characteristics of the load. Customer equipment, process controllers, and appliances will incorporate more electronics for "smartness," but will also be more sensitive to voitage and frequency fluctuations. These factors will necessitate greater emphasis on power quality and reliability of supply. Use of power electronics will also likely increase power frequency harmonics on the power system.

\subsection{ENVIRONMENT}

Environmental issues will be a driving factor in changing the power system characteristics. The increased emphasis on clean air will affect the generation fucl mix as well increase use of electricity 
by the end-use sector. Improved overall efficiency of energy production, delivery, and utilization will be emphasized. Use of renewable energy sources and storage will increase, and this increase will need to be integrated into the power system network in a safe, reliable, and controllable manner. Public concern about health effects from exposure to EMFs can have a significant impact on the ability to expand the transmission and distribution network to meet the future demand. Increased use of electricity for transportation will occur, changing the demand patterns.

\subsection{INSTITUTIONS}

Aging of the electric power supply infrastructure is presently of great concern and will continue. Large capital expenditures will be required to replace aging facilities, and extending the lives of many facilities will be the only viable option for the next decade. Thus, many present facilities will still be around in 2020.

Other concerns that could impede the system development towards 2020 are

- that competition among utilities in a deregulated environment would result in reduced couperation and sharing of results,

- that the present trend in the industry toward downsizing will result in loss of experienced pecple and expertise,

- that reduced quality and reliability of equipment could occur as the number of domestic suppliers are reduced and as equipment designs are driven by a world market rather than by the specific needs of U.S. utilities, and

- that increased rate of change of technologies could also result in reduced quality.

\subsection{SYSTEM DYNAMICS}

The dynamic characteristics of the electrical power delivery system are determined by all the elements constituting the system, e.g., generators, transmission and distribution circuits, and end-use technologies. In the present system, the controls and protection strategies have evolved to match the dynamic characteristics of the various components so as to provide the required level of system stability and reliability. Several factors will change the dynamics of the system by the year 2020 . These factors include the growing number of dispersed generation sources; generators with reduced or no rotating mass, such as superconducting generators and photovoltaic devices; and types of energy storage that have significantly differing dynamic characteristics, from superconducting magnetic energy storage to pumped hydroelectric storage. The dynamic behavior of the system will also change when the transmission system is accessed by non-utility generators that have varying degrees of controllability and unpredictable site locations. The increasing demand for power transfers will require more interconnections, and the reduced reserve margins of the system will require faster and more dynamic control and protection strategies than those available today. Massive amounts of data will be needed and generated, and this data must be reduced to a level where it can be handled effectively by the system operators as well as by the control and protection systems. The delivery system will be required to respond more quickly as time-of-day rates and flexible energy use in the end-use sector are increasingly put into practice. The growing complexity of the system will also result in new types of instabilities not encountered before.

Society's increasing reliance on electricity will require that the supply of electricity be more reliable, which, with the changing dynamics and increasing complexity of the system, means that conirol and protection strategies will become more automated and "smarter." Significant investments 
in R\&D will be needed to improve the speed and capabilities of computers, circuit breakers, and controls; to develop artificial intelligence systems and neural network systems; to devclop adaptive protection schemes and faster communication technologies; and to improve on- and off-line modeling capabilities of local and extended control areas of the network. 


\section{REQUIRED RESEARCH}

A number of factors that will influence the development of the electric power system over the next 30 years are discussed in Section 4. The largest effects of these factors will be caused by changes in technology and by regulations that will be implemented during the last half of this period. Many of the technologies will evolve from $R \& D$ that are in progress ncw or that should begin now.

Five areas that need R\&D were identified, all with nearly equal priority:

- effects of exposure to EMFs,

- real-time power system controls,

- higher-capacity transmission options,

- high-capacity power electronics, and

- energy storage.

The research needed for each of these is discussed in the following subsections.

\subsection{EFFECTS OF EXPOSURE TO ELECTRIC AND MAGNETIC FIELDS}

The issues of health effects from exposure to EMFs require urgent consideration on both shortterm and long-term bases and must be dealt with within the next five to ten years. ${ }^{2}$ Top priority should $b$, given to determining if there is a safe level of exposure to magnetic fields. The specific actions needed are providing national leadership on EMF issues (which includes improving public education and developing national standards), continuing scientific studies on biological systems, and developing mitigation method options.

- National Leadership. Strong national leadership is needed to solve the issues involved with EMFs. If the present practice of lengthy legal proceedings against electrical facilities based upon the EMF issues is allowed to continue, the reliability and adequacy of the nation's electric energy system will be in jeopardy. The federal government must assume a leadership role and act as a mediator between the electric utility industry and the growing public concern.

- Public Education. Results from research on EMFs must be presented to the public in an understandable way and in terms of the potential risks and hazards of EMFs compared with other societal risks.

- National Standards. At present, no uniform standard exists for exposure to EMFs. Scven states have set different standards for electric fields within transmission rights-of-way, as shown in Table 1, and others are expected to follow. Only one state, Florida, has set a standard for magnetic fields within rights-of-way. The benefit of a national standard for fields on rights-of-way would be to provide the public with a prudent measure of safety while allowing for the expanding use of electricity. Such transmission line standards should be

\footnotetext{
${ }^{2}$ A noted difference between this meeting with industry and a similar one held in 1985 is the emergence of the EMF issue as one of high priority. The previous meeting with utility industry representatives was held on October 23-25, 1985, in Secttle, Washington. The meeting is documented in the report Electric Energy Systems: Trends and Research and Development Needs for the 1990s, PNL-SA-14217, Pacific Northwest Laboratory, January 1987.
} 
proposed as an interim mecsure and should be based upon the available knowledge and present practices until agreement has been reached on the public health risks of cxposure to EMFs. Other standards for EMFs are equally important: exposure to fields from devices within the home and from other electric facilities must be considered as part of the overall process in establishing the public health risk.

Table 1. Seven states with field-strength limits for transmission line rights-of-way

\begin{tabular}{|c|c|}
\hline STATE & FIELD LIMIT \\
\hline Montana & $1 \mathrm{kV} / \mathrm{m}$ at edge of RoW in residential areas \\
\hline Minnesota & $8 \mathrm{kV} / \mathrm{m}$ maximum in RoW \\
\hline New Jersey & $3 \mathrm{kV} / \mathrm{m}$ at edge of Row \\
\hline New York & $1.6 \mathrm{kV} / \mathrm{m}$ at edge of RoW \\
\hline North Dakota & $9 \mathrm{kV} / \mathrm{m}$ maximum in Row \\
\hline Oregon & $9 \mathrm{kV} / \mathrm{m}$ maximum in Row \\
\hline \multirow[t]{7}{*}{ Florida } & $10 \mathrm{kV} / \mathrm{m}$ maximum for $500-\mathrm{kV}$ lines in RoW \\
\hline & $2 \mathrm{kV} / \mathrm{m}$ maximum for $500-\mathrm{kV}$ lines at edge of RoW \\
\hline & $8 \mathrm{kV} / \mathrm{m}$ maximum for $230-\mathrm{kV}$ and smaller lines in RoW \\
\hline & $2 \mathrm{kV} / \mathrm{m}$ maximum for $230-\mathrm{kV}$ and smaller lines at edge of RoW \\
\hline & $200 \mathrm{mG}$ fo. $500-\mathrm{kV}$ lines at edge of RoW \\
\hline & $250 \mathrm{mG}$ for double circuit $500-\mathrm{kV}$ lines at edge of RoW \\
\hline & $150 \mathrm{mG}$ for $230-\mathrm{kV}$ and smaller lines at edge of RoW \\
\hline
\end{tabular}

Source: I. Nair et al., "Power-frequency Electric and Magnetic Flelds: Exposure, Effects, Research, and Regulatlon," OTA contractor report, Carnegie Mellon University Department of Engineering and Public Policy, Jan. 16, 1989.

- Scientific Studies. The basic studies and experiments on biological systems (cells, tissues, and whole animals) should be expanded and accelerated to determine any harmful effects to humans from exposure to EMFs. Priority should be given to studies that will determine if there are safe levels of exposure to magnetic fields. Epidemiology and risk analysis are also important elements in a comprehensive study of EMF effects and should be part of the total national effort.

- Options for Mitigation. Options for methods to mitigate exposure to EMFs should be pursued in parallel with the basic scientific studies. Although there are techniques for reducing the exposure to EMFs from transmission lines and other sourees, the cost of the options will depend en how low the level of exposure must be. However, the scientific studies to date do not indicate whether magnetic fields might become benign at a lower level, or even whether a lower level of exposure would be safer. Any mitigating action will come at an increased cost, but the added costs might be required to satisfy the public. It is therefore important to develop options to minimize these costs. 


\subsection{REAL-TIME POWER SYSTEM CONTROL}

In the future, the increasing competition between utilities and the growth in NUGs that will be facilitated by legislation and deregulation will raise issues about how power system operation will be coordinated among competing companies. New technologies with differing dynamic characteristics will need to be integrated and controlled, and, for the increasingly loaded transmission system, the path of the power flow must be controlled. Control areas may also be larger than at present, comprising many utilities similar to the NERC Reliability Councils. The dynamic characteristics of the electric delivery system will change dramatically as new generating sources and storage technologies are incorporated into the network and as the system becomes increasingly interconnected. At the same time, system reliability must be maintained, which will result in the need for faster near-real-time power system control. Also, faster data analysis and controls will be an absolute system requirement to maintain the system stability and the high reliability of the clectric supply.

The key to near-real-time control is the ability to monitor essential parameters on the power system in real time with precise time synchronization, to communicate this information to a control point, to analyze the data with the aid of sophisticated computers and network models, to decide upon a control strategy or action, and to transfer this decision to remotely controlled devices to effect the required system change. The ultimate challenge is to complete these tasks faster than the state of the system changes.

The electric network has some unique features that make real-time control difficult. First, the production, delivery, and use of power is dynamic and continuously changing; i.c., generation must follow demand, or demand must be controlled to match generation resources. Second, the power system is complex and extensive and comprises a large number of interconnected components. It requires large-scale on-line and off-line models with a large number of monitoring and control points. And third, the geographical dispersion of the power system makes communications critical to the success of real-time monitoring and control. The following four areas are research topics considered important for meeting the changing system conditions:

- System Architecture. New technologies in the power system architecture, such as energy storage and load control, will provide increased flexibility in matching available gencration with system load. Other transmission technologies [i.e., high-voltage de (HVDC) transmission, static var compensators, phase shifters, and various types of controls to manipulate the ac flow / will provide increased precision in power flow control of transmission and distribution circuits. However, this added flexibility during operation increases the complexity of the system's control problem and increases the need for real-time measurements and information management to support operating decisions. Specific research needs include defining the power system control objectives; defining the measurement, communication, and computation required to support real-time control, including data exchange between utilities; and developing control algorithms to ensure reliable and economic operation.

- New Modeling Techniques. New modeling techniques will be required that are on-line for control and off-line for planning. Off-line planning models are needed for long-term planning for site selection and system expansion. These techniques will be important when adding NUGs, for which siting is both unpredictable and outside of utility control, as well as when planning for renewable resources such as wind and solar-based gencration that do not fit conventional planning and siting models well. A shorter-term (5-10 min.) modeling capability for buying and selling power will be needed to allow the utilities to continue to change rates during certain periods. The research should include problem formulations, component model development, development of numerical solution techniques, and model verification. The models will include 
r.ww component and device models, such as a superconducting gencrator, or system models, such as the reformulation of the basic power-flow model. The models must also incorporate key utility functions such as economic dispatch, environmental dispatch, unit commitmens, power flow, stability, system security assessment, contingency analysis, and load modeling.

- Computer, Communication, and Sensor Technology. Computers, communications systems, and sensors are becoming vital parts of operation and control of the electric power system so that the state of the system and power flows can be assessed and simulated at any momeni. Advances in computer technology must be adapted for application in power systems modeling and controls. Supercomputers and parallel computing technology, which are in limited use today by the power industry, will be necessary for use in real-time controls and near-real-time models. Applications unique to the power industry require specialized computer processors, specilically in the class of applications in which the simultancous solution of large sets of equations is required. Real-time information will play an essential role in future power system operations, and this role requires a high-speed, reliable communications system that can be installed over a large service territory at a reasonable cost. The development of sensors that are inexpensive relative to today's technology and that are immune to electromagnetic interference, such as fiber optics and lasers, will also be required.

- Information Management Methods. As the electric power system grows and becomes more automated, the amount of data generated increases exponentially, and the operation of the system becomes more complex, requiring the system operators to manage vast amounts of data. In order to effectively manage this situation, methods of data reduction, user-friendly displays, and intelligent $\mathrm{man} / \mathrm{machine}$ interfaces will be needed. Artificial intelligence, expert systems, ne: ral networks, and data base design are areas that must be developed to help the power system operator control the electrical delivery system.

\subsection{HIGHER-CAPACITY TRANSMISSION OPTIONS}

The increasing use of transmission lines for bulk power transfers and the growing demand for access by NUGs will continue to stress the transmission system. In addition, because of the difficulty in obtaining new rights-of-way, the use of transmission corridors, new or existing, must be maximized by increasing the amount of power that can be transmitted through these corridors. Joint planning for use of rights-of-way by the various utilities and states should be considered. The following four areas are important $\mathrm{R} \& \mathrm{D}$ issues for ensuring adequate transmission capacity:

- Advanced Transmission Concepts. New designs for transmission lines that can increase the power transfer in a given corridor and can also mitigate EMFs are needed to meet the increasing transmission demand. The development of overhead lines for ac and de should be eontinued, and alternatives such as higher-phase order lines (6-phase and 12-phase) should be seriously considered. Other alternatives include acrial cable as a low-cost alternative to underground cables, hybrid designs with ac and de lines sharing the same tower, and superconducting transmission cables.

- New Materials. Materials research is key to improving the efficiency, reliability, and power density of the transmission and distribution system. This research is also gaining in importance because of the aging of the power system, which requires information about the remaining life of the materials used and about the compatibility and aging characteristics of new materials. The purpose of materia: : R\&D would be to increase dielectric strength, to reduce energy losses, and to reduce physical size and weight (to increase compactness) of the transmission and distribution equipment. The use of better materials in the construction of transmission lines will allow the 
power density of the corridor to be increased. Materials rescarch must be provided with steady, patient funding, since it is basic and long-term research.

- "Smart" Components. "Smart" components will be an indispensable part of the future power delivery system. To improve the power transfer capability of the transmission system, the state of the system as well as that of the individual components must be known at any time. The basic components of a transmission system in addition to the line include transformers, circuit breakers, line-compensation equipment, relays, and measuring instruments such as voltage and current transformers. "Smart" refers to the ability of a component to monitor and diagnose its internal functions and condition (such as current, voltage, temperature, contamination, and deterioration) and to indicate its status. If the status of the individual components can be known more precisely, the overall dynamic rating can be increased.

- Improved Maintenance. As the power plants and the transmission system in this country dge, the high cost of capital and the need to expand the power delivery sysiem will prevent significant renewal of existing facilities. Better maintenance techniques will be required to help extend the useful life of existing equipment. The failure rate of transmission system components as they age is unknown, and better maintenance may be needed should excessive failures occur. Also, as the loading of the system increases, the availability of lines must increase; and improved live-line maintenance techniques will keep a line in service while it is being maintained or even upgraded. The use of robotics and automated equipment and the analysis of failure signatures are techniques that should be pursued to improve maintenance and availability of the system.

\subsection{HIGH-CAPACITY POWER ELECTRONICS}

Load flow in the power system of the future will become complex because the system will expand and become more highly stressed to meet energy demand and because dispersed and smaller generating units and storage facilities will be added and interconnections increased. Control of this load flow will become necessary to facilitate bulk power transactions and to reduce or prevent unintended loop flows through parts of the interconnected neighboring system. Power electronics will have a key role in providing this control, because power electronics can provide the much greater speed and flexibility needed. However, power electronic devices that have higher current and voltage ratings than those presently available and that meet reliability criteria for power equipment must be developed. The development of power electronics today has focused mainly on devices operating at lower voltages and currents like those typically found in consumer electronics and motor controls. Three foci for the development of power electronic devices for utility applications were identified:

- Converter Equipment. De transmission can be controlled more casily than ac transmission; therefore, de current is used to link the four major NERC interconnection areas as well as to transmit large blocks of power over long distances. A major expense of the ac-to-de conversion lies in the power electronic thyristor valves and the associated technology. Today's converter stations are complicated in design because thousands of thyristors must be used in series and parallel combinations to provide the voltage and current levels for HVDC conversion. Power electronic devices with higher current and voltage capability will simplify this design with a resulting reduction in cost.

- Interrupting Equipment. One of the basic operations performed daily on a utility system is opening or closing a circuit breaker (switch). The power delivery system of the future will require higher-speed operation and separation during abnormal conditions than that which can be achieved with today's mechanical circuit breakers. Power electronics also offer the speed and precise timing needed to perform synchronous switching. 
- Load Flow Controls. Power electronics make possible the control of individual components of a power system, and thus can be used to control the load flow in transmission lines. Applications include controls for reactive power-line compensation, such as static var compensators (i.e., capacitors and reactors) and other devices.

\subsection{ENERGY STORAGE}

As the diversity of generating sources increases, the balancing act that utilities perform to synchronously match generation to load will become more difficult. Energy storage technology has the potential to (1) alleviate the need to match generation capacity with demand at all times and (2) defer new generation and transmission construction. The primary technology for energy storage today is pumped hydro, and the benefits have been primarily attributable to peak-shaving. However, a number of other technologies for large-scale electrical energy storage are under development. These include batteries, compressed-air energy storage (CAES), and superconducting magnetic energy storage (SMES). Important benefits of storage technologies, in addition to diurnal duty, include load following, system stability, and var control. For storage to be considered as an economic alternative, the installed costs per kilowatt must be comparable to those of a peak generating plant. Along with research leading to lower capital cost for the various storage alternatives, methods need to be developed that allow utilities to evaluate the full system benefits of storage.

Total System Benefits. The total system benefits of energy storage must be determined, including costs and the optimal size and location of storage sites in the electric utility system. The total system benefits of smaller storage technologies, such as batteries and SMES, dispersed through a utility network and connected at the substation level, can be large but are not as well understood. The development of storage technology for electric utility applications should continue. 


\section{RESEARCH LEADERSHIP}

An electric energy delivery system that reliably supplies sufficient electric power at the lowest possible cost to meet the nation's needs is vital to the economic health of the United States. To meet the challenges facing the national supply and delivery of electric power in the future, all parties concerned with R\&D of supply and delivery technologies for electric energy must cooperate and seek to leverage the limited funds available. The relative magnitude of the support for R\&D in electrical systems by selected federal and private organizations is shown in Table 2 .

Accomplishing the tasks facing the nation requires a high level of cooperation between the government and the utility industry. This report outlines the beginning of such a process initiated by DOE in cooperation with the Power Marketing Administrations (PMAs) that has enlisted both public- and private-sector interests. DOE should, with the assistance of the PMAs, take the lead within the federal government to conduct a series of meetings involving EPRI, the utility industry, and universities to further develop this research plan, including setting prioritics for research arcas and identifying collaborative R\&D opportunities. Coordination of R\&D and demonstration is needed among the various performers to ensure that the $R \& D$ of promising technologies is brought to fruition in the marketplace by the timely transfer of results and technologies. Similar coordination and cooperation is needed to prove the technical feasibility of materials and concepts.

Table 2. Support for rescarch and development in clectrical systems in 1989, sclected groups

\begin{tabular}{||l|c|}
\hline \multicolumn{1}{|c|}{ ORGANIZATION } & SUPPORT (\$ MILLION) \\
\hline \hline $\begin{array}{l}\text { Electric Power Research Institute (EPRI), } \\
\text { Electric Systems Division }\end{array}$ & 43.0 \\
\hline $\begin{array}{l}\text { Empire State Electric Energy Research Corp. } \\
\text { (ESEERCO) }\end{array}$ & 2.8 \\
\hline DOE, Bonneville Power Administration & 5.7 \\
\hline DOE, Electric Energy Systems & $24.3^{\mathrm{a}}$ \\
\hline Tennessee Valley Authority & 2.8 \\
\hline American Electric Power & 5.6 \\
\hline Southern California Edison & $>10.0$ \\
\hline New York State Utilities & $17.0^{b}$ \\
\hline
\end{tabular}

Includes \$12.1 million for high-temperature superconductivity.

'Includes contributions to EPRI, ESEERCO, and the New York State Energy Research and Development Agency.

Contrary to popular conceptions, neither the technology employed nor the technology needed by the electric power industry are mature. Considerable challenges face the industry to meet the growing demand for energy. These challenges can be met only by an aggressive and coordinated R\&D program, conducted with cooperation between the industry and the federal government. This initiative is intended to be an integral part of and complement to the utility industry R\&D activities, from collaborative research planning to performance in service. DOE must play a key role in this framework as the only party with the resources to take a long-term view of technology needs and 
national issues. The mission of DOE should therefore be broad, with programs in fundamental research as a strong component, and should be focused on research issues that require long-term support or that require solutions far in the future. Through such a mission, the DOE program will provide the necessary underpinning for a strategic $R \& D$ program and will be a strong complement to the necessarily narrower focus on R\&D that must be taken by the industry. Over the ycars, federai funding for utility R\&D has fluctuated significantly and has not always reflected the concurrent need. A consistent long-term commitment from the federal government is paramount. It is also critical that the industry has a role in advising the government on its R\&D portfolio and directions. This will accomplish the dual purpose of insuring relevant research programs and facilitating technology transfer. 


\section{ACKNOWLEDGMENTS}

The meeting in Denver on March 19 and 20, 1990, was organized on behall of the U.S. Department of Energy, Office of Energy Management, and was conducted by the Power Systems Technology Program at Oak Ridge National Lahoratory and by Energetics, Inc. The authors are grateful for the assistance of J. W. Hurwitch and H. Lowitt of Encrgetics, Inc., in preparing this report and facilitating the workshop. The time and effort given by the attendees are gratefully acknowledged. 


\section{APPENDIX A: STRAWMAN SYSTEM 2020}

\section{GENERATION}

- Over $50 \%$ of all new units will be non-utility owned, consisting of

- cogeneration,

- independent power producers, and

- developers of renewable technologies.

- Power plant unit sizes will be smaller (50-600 MW).

- Nuclear units will emerge, increasing in percentage beginning in 2010.

- Coal plants will decrease in percentage because of environmental constraints.

- Gas and oil plants will remain a constant percentage.

- Renewable energy and fuel-cell plants will substantially increase, making up $20 \%$ of all generation, including hydro.

- Plant controls will be more sophisticated because of a greater mix of generator types and system dynamics.

\section{STORAGE}

- Systems will require energy storage for both load and demand control and for system stability.

- Larger units (250-1000 MWh) will use SMES, hydro, and batteries.

- Ten percent of system peak demand will be served by electrical storage by 2020 .

\section{TRANSMISSION}

- Line loading will increase substantially because of difficulty in establishing new rights-of-way.

- Load growth will continue, requiring more bulk power movement.

- Capacity ratings will exceed present standards and potentially will reduce reliability. 
- Blackouts and brownouts will occur if status quo is maintained, i.e., with present loading limits, control devices, and operating practices.

- New transmission lines may be built if the EMF issue is resolved or if new construction standards (including untergrounding) are applied, such as

- superconducting cables and

- multiphase (6- or 12-phase) circuits.

- New interregional ties will be attempted but will be successful only after public acceptance of the "risk" of electromagnetic fields.

\section{SYSTEM PLANNING CONTROLS, COMMUNICATION, AND DISPATCH}

- Adaptive relays and controls will be required, using the best artificial intelligence and analysis:

- real-time data gathering,

- Cast data filtering, and

- near-real-time analysis and action.

- Protective relays will be needed that automatically adapt to changing system conditions.

- Distribution system automation will reduce losses and will improve system reliability.

- New interactive/predictive economic and system operations models will be attempted that are able to predict problems and to optimize reliability vs cost issues in near-real-time. 


\section{APPENDIX B: AGENDA}

\section{MAINTAINING ELECTRIC POWER SYSTEM PERFORMANCE: \\ Preparing for the Year 2020}

Objective: To define the requirements for the electric power system of the year 2020 and to develop an R\&D strategy to meet these requirements.

Monday, March 19, 1990

Time

1:00-1:10 p.m.

DOE Welcome/Workshop Purpose and Logistics Russell Eaton, DOE

1:10-1:30 p.m. Driving Forces and Outlook of Electric Power System of $\mathbf{2 0 2 0}$

Tom Weaver, WAPA

1:30-4:30 p.m. Discussion Toward Consensus of Each Aspect of the 2020 Power System, Resultant Implications, and Required Solutions/Approaches Steinar Dale, ORNL

4:30-6:00 p.m. Small Group Discussions of the R\&D Requirements for the 2020 Flectric Power System

Tom Weaver - Group Leader, WAPA Charles Clark - Group Leader, BPA Howard Lowitt - Facilitator, Encrgetics Jon Hurwitch - Facilitator, Energetics

6:00 p.m.

Adjournment
Tucsday, March 20, 1990

Time

Activity

8:00-10:45 a.m. Small Group Discussion Continues on R\&D Requircments Tom Weaver - Group I.cader, WAPA Charles Clark - Group I_cader, BPA Howard Lowitt - Facilitator, Fnergetics Jon Ilurwitch - Facilitator, Energetics

10:45-11:00 a.m. Break

11:00-12:00 a.m. Presentation of Identificd R\&I) Necds Tom Weaver - Group Leader, WAPA Charles Clark - Group L_cader, BPA

12:00-1:00 p.m. I.unch

1:00-3:30 p.m. Plenary Discussion to Determine R\&L Priorities, Objectives, and Sct 'Jule Stcinar Dale, ORNI

3:30-3:45 p.m. Brak

3:45-4:30 p.m. Plenary Discussion of l'uture Activities and Group Involvement Stcinar Dalc, ORNI.

4:30 p.m. $\quad$ Adjournment 


\section{APPENDIX C: LIST OF PARTICIPANTS}

Robert E. Benson

Chief Electrical Engineer

New York State Electric \& Gas Corp.

4500 Vestal Parkway East

Binghamton, NY 13903

Larry Bressler

Western Area Power Administration

P.O. Box 3402

Golden, CO 80401

Charles F. Clark

Chief Engineer

Bonneville Power Administration

P.O. Box 3621

Portland, OR 97208

Lynn Coles

Principal Policy Advisor

SERI

1617 Cole Boulevard

Golden, CO 80401

Steinar J. Dale

Manager, Power Systems Technology Program

Building 3147, MS 6070

Oak Ridge National Laboratory

P.O. Box 2008

Oak Ridge, TN 37831-6070
Raymond Dunlop

Director of Research

New England Power Scrvice Co.

25 Research Drive

Westborough, MA 01582

Russell Eaton, III

Acting Director

Office of Energy Storage and Distr.

U.S. Department of Energy

CE-32, Room 5E036

1000 Independence Avenue SW

Washington, DC 20585

Jimi Evans

Director, Power Production

Edison Electric Institute

1111 19th St, NW

Washington, DC 20036

Robert E. Hebner

Acting Deputy Director

Center for Electronic \& Electrical

Enginecring

National Institute of Standards and Technology

Room 5358 , Bldg. 220

Gaithersburg, MD 20899 
Wayne Hilson

Manager, Transmission and Electrical Systems Department

Tennessce Valley Authority

Missionary Ridge, 3 North 41

1101 Market Street

Chattanooga, TN 37402-2801

Jon W. Hurwitch

Program Manager

Energetics, Inc.

9210 Route 108

Columbia, MD 21045

Joe Iannucci

Pacific Gas \& Electric

3400 Crow Canyon

San Ramon, CA 94583

Kenneth W. Klein

Consultant

Energetics, Inc.

501 School Street SW

Washington, DC 20024

Joseph L. Koepfinger

Director, Systems Studics and Research

Duquesne Light Company:

One Oxford Center

301 Grant Street

Pittsburgh, PA 15279
Walter E. Mycrs

R\&D Manager

Bonneville Power Administration

P.O. Box 3621

Portland, OR 97208

Thomas R. Schneider

Senior Science Advisor

Electric Power Research Institute

3412 Hillview Avenue

P.O. Box 10412

Palo Alto, CA 94303

Virgil Schafer

Enginecring Division Manager

Tri-State Generation and Trans. Assoc.

12076 Grant Street

Denver, CO 80233

C. H. (Dan) Shih

Manager, Electrical Research

American Electric Power Service Corp.

1 Riverside Plaza,

Columbus, $\mathrm{OH} 43215$

John P. Stovall

Research Staff

Power Systems Technology Program

Building 3147, MS 6070

Oak Ridge National Laboratory

P.O. Box 2008

Oak Ridge, TN 37831-6070)

Howard Lowitt

Vice President

Energetics, Inc.

9210 Route 108

Columbia, MD 21045 
Jan Wagers

Power Systems Planning

City of Colorado Springs

Department of Utilities

30 South Nevada

Colorado Springs, CO 80903

Thomas L. Weaver

Assistant Administrator for Engineering

Western Area Power Administration

P.O. Box 3402

Golden, CO 80401

Frank Young

Director

Electric Systems Division

Electric Power Research Institute

P. O. Box 10412

3412 Hillview Avenue

Palo Alto, CA 94303 


\section{INTERNAL DISTRIBUTION}

1. P. R. Barnes

2. V. D. Baxter

3. R. B. Braid

4. E. D. Copenhaver

5. G. E. Courville

6. F. A. Creswick

7-16. S. J. Dale

17. P. D. Fairchild

18. P. S. Gillis

19. E. L. Hillsman

20. J. O. Kolb

21. M. A. Kuliasha

22. V. C. Mei

23. W. R. Mixon
24. M. B. Parrott

25. S. L. Purucker

26. D. T. Rizy

27. B. E. Tonn

28. J. W. Van Dyke

29. R. B. Stone

30. J. N. Stone

31. ORNL Patent Office

32. Central Research Library

33. Document Reference Section

34. Y-12 Technical Library

35-37. Laboratory Records

38. Laboratory Records-RC

\section{EXTERNAL DISTRIBUTION}

\section{$\underline{\text { ORNL LIST }}$}

39. J.C. Allen, Director, T\&D Engineering, Southwestern Electric Power Co., P.O. Box 21106, Shreveport, LA 71156.

40. Richard W. Allen, Chief Distribution Engineer, New England Power Service Co., 25 Research Drive, Westboro, MA 01582.

41. Michacl R. Apprill, Vice President, Engineering \& System Operations, Missouri Public Service, 10700 East 350 Highway, Kansas City, MO 64138.

42. Daniel L. Bartel, Director of Electrical Operations, Wisconsin Power \& Light Company, 222 West Washington Ave., P.O. Box 192, Madison, WI 53701-0192.

43. J. E. Benning, Vice President, Power System Engineering/Operations, PSI Energy, 1000 East Main Street, Plainfield, IN 46168.

44. Robert E. Benson, New York State Electric \& Gas Corp., 4500 Vestal Parkway East, Binghamton, NY 13903. 
45. Gerald D. Birney, Director, Division of Substation Design, Western Area Power Administration, P.O. Box 3402, Golden, CO 80401.

46. Peter D. Blair, Congress of the United States, Office of Technology Assessment, Washington, DC 20510.

47. W. Terry Boston, Manager of Regional Operations, Tennessee Valley Authority, 6N 31B Signal Place, 1101 Market Strect, Chattanooga, TN 37402-2801.

48. Larry Bressler, Western Area Power Administration, P.O. Box 3402, Golden, CO 80401.

49. Robert H. Brewer, Office of Energy Storage \& Distr., U.S. Department of Energy, CE141, 5G-023/FORS, 1000 Independence Avenue SW, Washington, DC 20585.

50. Bruce G. Buchanan, Energy Division Advisory Committee 1990, Computer Science Department, University of Pittsburgh, 206 Mineral Industries Building, Pittsburgh, PA 15260.

51. William J. Budney, Vice President, Distribution Systems, Public Service Electric \& Gas Co., 80 Park Plaza, Newark, NJ 07101.

52. Jerry Campbell, Executive Director, Tennessee Valley Public Power Assoc., 1201 Chestnut Street, Chattanooga, TN 37402.

53. Charles F. Clark, Chief Engineer, Bonneville Power Administration, P.O. Box 3621, Portland, OR 97208.

54. Lynn Coles, Principal Policy Advisor, SERI, 1617 Cole Boulevard, Golden, CO 80401.

55. John J. Cuttica, Energy Division Advisory Committee 1990, Vice President, End Use, Gas Research Institute, 8600 W. Bryn Mawr Avenue, Chicago, IL 60631.

56. Larry W. DeJong, Vice President, Transmission \& Distr., Iowa Public Service Company, P.O. Box 778, Sioux City, IA 51102.

57. Arthur R. Donnell, Vice President, Electric Operations, Northwestern Public Service Co., 3rd St. \& Dakota Ave., S.E., Huron, SD 57350.

58. Raymond Dunlop, Director of Research, New England Power Service Co., 25 Research Drive, Westborough, MA 01582.

59. Russell Eaton, III, Director, Advanced Utility Concept Division, Office of Energy Management, U.S. Dept. of Energy, CE-142, Room 5E036, 1000 Independence Ave. SW, Washington, DC 20585.

60. Hussein Elbadaly, Underground T\&D Research Manager, Consolidated Edison Company, 4 Irving Place, New York, NY 10003. 
61. Jim Evans, Director, Power Production, 1111 19th St., NW, Washington, DC 20036.

62. Martin E. Gordon, National Rural Electric, Cooperative Association, 1800 Massachusetts Ave., N.W., Washington, DC 20036.

63. James D. Gregory, Manager, Power \& System Engineering, Southern Company Services, Inc., P.O. Box 2625, Birmingham, AL 35202-2625.

64. Imre Gyuk, Office of Energy Management, U.S. Department of Energy, CE-141, 5E036/FORS, 1000 Independence Avenue SW, Washington, DC 20585.

65. Robert E. Hebner, Deputy Director, Center for Electronic \& Elect. Engr., NIST Room B358, Bldg. 220, Gaithersburg, MD 20899.

66. Wayne Hilson, Manager, Transmission \& Electrical Systems Department, Tennessee Valley Authority, Missionary Ridge, 3 North 41, 1101 Market Street, Chattanooga, TN 37402-2801.

67. N. G. Hingorani, Electric Power Research Institute, 3412 Hillview Avenue, P.O. Box 10412 , Palo Alto, CA 94303.

68. Allen Hirsch, Energy Division Advisory Committee 1990, Vice President, Environmental Sciences, Director, Washington Operations, Midwest Research Institute, 5109 Leesburg Pike, Suite 414, Falls Church, VA 22041.

69. E. R. Holcomb, Vice President, Texas Utilities Electric Co., 1506 Commerce Street, Dallas, TX 75201

70. Kirby C. Holte, Southern California Edison Co., 6090 N. Irwindale Ave., Irwindale, CA 91702.

71. Michael B. Hunter, Director, Power Systems Operations, Puget Sound Power \& Light Co., 13635 N.E. 80th Street, Redmond, WA 98052-4098.

72. Jon W. Hurwitch, Program Manager, Energetics, Inc., 7164 Gateway Drive, Columbia, MD 21046.

73. Joe Iannucci, Pacific Gas \& Electric, 3400 Crow Canyon, San Ramon, CA 94583.

74. R. Kennon, Electric Power Research Institute, 3412 Hillview Avenue, P.O. Box 10412, Palo Alto, CA 94303.

75. Jack L. King, Sr. Vice President, System Executive Operations, Entergy Corporation, P.O. Box 61005, 225 Baronne Street, New Orleans, LA 70161.

76. Harold Kirkham, Jet Propulsion Laboratory, 4800 Oak Grove Drive, Pasadena, CA 91109.

77. Kenneth W. Klein, Consultant, Energetics, Inc., 501 School Street SW, Washington, DC 20024. 
78. Kurt Klunder, Office of Energy Storage \& Distr., U.S. Department of Energy, CE-14, 5F059/FORS, 1000 Independence Avenue SW, Washington, DC 20585.

79. Joseph L. Koepfinger, Director, Systems Studies and Research, Duquesne Light Company, One Oxford Center, 301 Grant Street, Pittsburgh, PA 15279.

80. Robert A. Kramer, Director of Electric Operations, Northern Indiana Public Service Company, 5265 Hohman Avenue, Hammond, IN 46320.

81. J. S. Lawler, Professor, University Of Tennessee, Electrical Engineering Dept., Knoxville, TN 37916.

82. James Lee Layton, Vice President, Systems Operation, Carroll Electric Membership Corp., 155 Temple Road, Carrollton, GA 30117.

83. Gary R. Leidich, Director, System Planning Engineering Dept., Centerior Energy, 6200 Oak Tree Boulevard, Independence, $\mathrm{OH} 44131$.

84. Richard C. Liebentritt, Division Manager-Engineering, Omaha Public Power District, 444 South 16th Street Mall, Omaha, NE 68102-2247.

85. Howard Lowitt, Vice President, Energetics, Inc., 7164 Gateway Drive, Columbia, MD 21046.

86. Steve R. Mendoza, Director of Electrical Engineering, Salt River Project, P.O. Box 52025, Phoenix, AZ 85072-2025.

87. S. Nilsson, Electric Power Research Institute, 3412 Hillview Avenue, P.O. Box 10412, Palo Alto, CA 94303.

88. J.J. Pachot, R\&D Manag :r, Bonneville Power Administration, P. O. Box 3621, Portland, OR 97208

89. Thomas W. Reddoch, Vice President, Electrotek Concepts, Inc., 10305 Dutchtown Road, Suite 103, Knoxville, TN 37932.

90. T. J. Reed, Manager, EPRI/UTTF, Westinghouse Electric Corp., R.D. \#2, Box 547, Ruffs Dale, PA 15679

91. Henry I. Robidoux, Vice President, T\&D Engr. \& Operations, Metropolitan Edison Company, 2800 Pottsville Pike, P.O. Box 16001, Reading, PA 19640-0001.

92. Dietrich J. Roesler, Dept. Of Energy, CE-141, Office of Energy Management, Forrestal Building, MS-5\#036, 1000 Independence Ave., SW, Washington, DC 20585.

93. Virgil G. Rose, Sr. Vice President \& General Manager, Pacific Gas \& Electric Co. , 123 Mission Street, San Francisco, CA 94160. 
94. Cary H. Rush, General Manager, Engineering \&, Construction Dept., Philadelphia Electric Co., 2301 Market St. (S25-1), Philadclphia, PA 19101.

95. R. Samm, Electric Power Rescarch Institute, 3412 Hillview Avenue, P.O. Box 10412, Palo Alto, CA 94303.

96. Robert San Martin, Deputy Assistant Secretary, U.S. Department of Energy, CE-30, 6C026/FORS, 1000 Independence Avenue, Washington, DC 20585.

97. J. E. Scalf, Vice President, Plant Support, Florida Power \& Light Company, P.O. Box 14000, 700 Universe Blvd., Juno beach, FL 33408.

98. Virgil Schafer, Engineering Division Manager, Tri-State Gencration \& Trans. Assoc., 12076 Grant Street, Denver, CO 80233.

99. William G. Schiffmacher II, Vice President, Engrg. \& Construction, Long Island Lighting Company, Office of Engineering \& Construction, 1660 Walt Whitman Road, Melville, NY 11747.

100. Thomas R. Schneider, Senior Science Advisor, Electric Power Rescarch Institute, 3412 Hillview Ave., P.O. Box 10412, Palo Alto, CA 94303.

101. D. K. Sharma, c/o Senator Wendell H. Ford, SR-173A, Washington, DC 20510.

102. C. H. Shih, Manager, Electrical Research, American Electric Power Service Corp., 1 Riverside Plaza, Columbus, $\mathrm{OH} 43215$.

103. William E. Shula, Electric Power Research Institute, Electrical Systems Division, 3412 Hillview Ave., P. O. Box 10412, Palo Alto, CA 94303.

104. Gerald I. Stillman, Vice President, Research \& Development, New York Power Authority, 1633 Broadway, New York, NY 10019.

105. V. Tahiliani, Electric Power Research Institute, 3412 Hillview Avenue, P.O. Box 10412, Palo Alto, CA 94303.

106. Loren L. Taylor, Vice President Transmission \& Inter-Utilities Services, Northern States Power Company, 414 Nicollet mall, Minneapolis, MN 55401.

107. A. Norman Terreri, Senior Vice President, Electrical Operations, Green Mountain Power Corp., P.O. Box 850, South Burlington, VT 05402.

108. Malcolm V. Thaden, Manager, Substation Engineering, Potomac Electric Power Co., 1900 Pennsylvania Ave., NW, Room 311, Washington, DC 20068.

109. Gerald F. Thompson, Manager, Transmission Engrg., Northeast Utilities Service Co., P.O. Box 270, Hartford, CT 06141-0270. 
110. G. H. Usry, Athens Utilities, Board, P. O. Box 689, Athens, TN 37303-0689.

111. Jan Wagers, Power Systems Planning, City of Colorado Springs, Department of Utilities, 30 South Nevada, Colorado Springs, CO 80903.

112. Thomas L. Weaver, Assistant Administrator for Engineering, Western Area Power Administration, P.O. Box 3402, Golden, Co 80401.

113. Leonard B. Wideman, Manager, Engineering Planning, Houston Lighting \& Power Co., P.O. Box 1700, Houston, TX 77001.

114. Frank Young, Director, Electric Systems Division, Electric Power Research Institute, P.O. Box 10412, 3412 Hillview Avenue, Palo Alto, CA 94303.

115. Robert M. Youngs, Deputy Chief Engineer, Seattle City Light, 1015 Third Avenue, Seattle, WA 98104.

116. James A. Zychinski, Manager, Distribution Planning, \& District Engineering, Union Electric Company, P.O. Box 149, M/C661, St. Louis, MO 63166.

117. Office of the Assistant Manager for Energy Research and Development, U.S. Dept. of Energy, P.O. Boox 2001, Oak Ridge, TN 37831-8600

118.-127. OSTI, U.S. Department of Energy, P.O. Box 2002, Oak Ridge, TN 37831-6501 

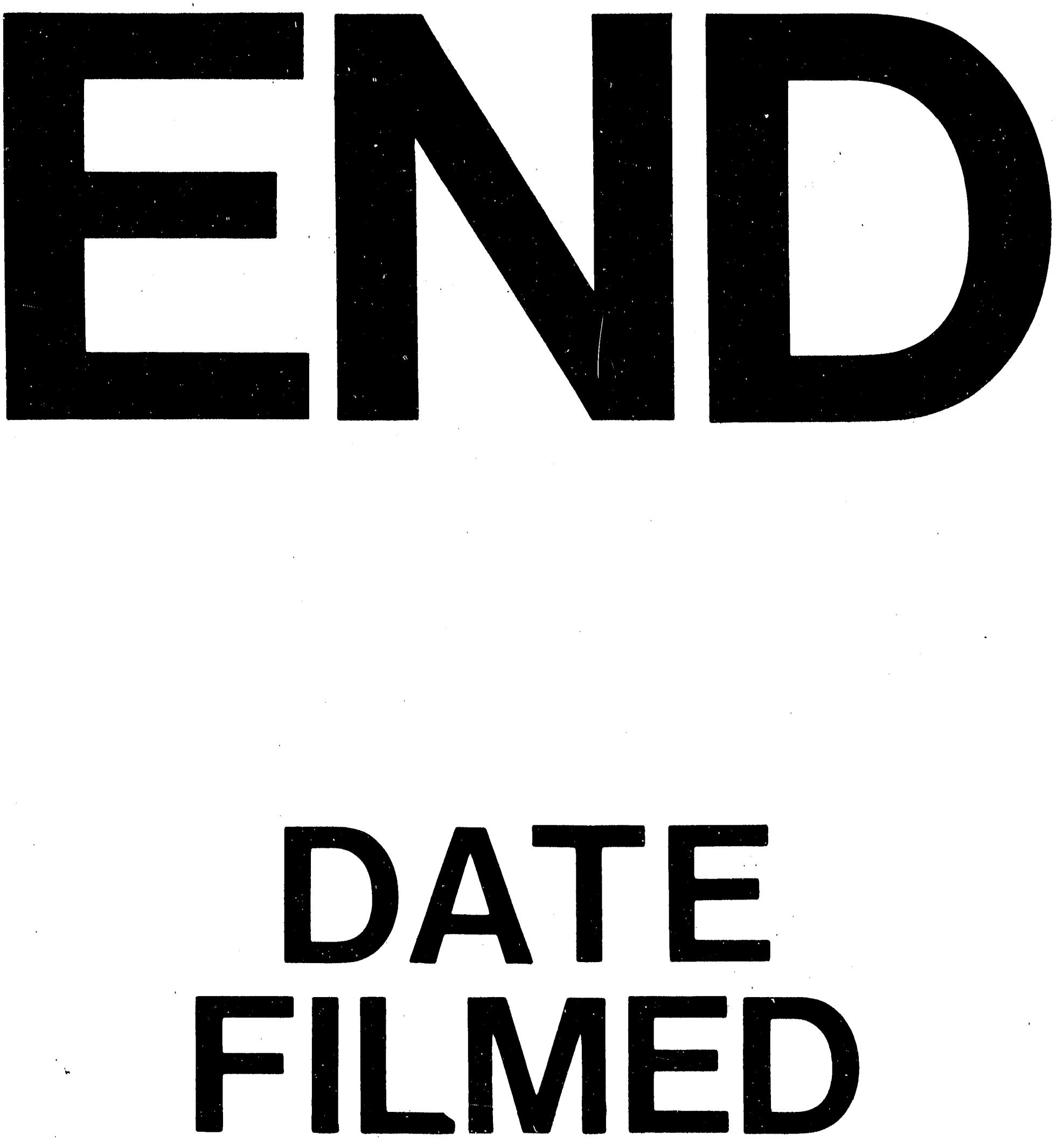

1

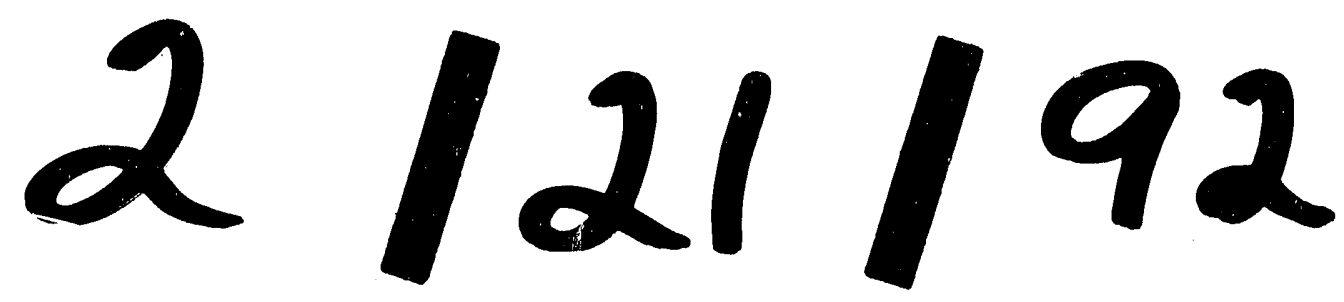


